\title{
IMPLEMENTASI STRATEGI MANAJEMEN RITEL DALAM MENINGKATKAN KEUNGGULAN BERSAING
}

\author{
Sanny Ekawati ${ }^{1}$, Thio Lie Sha ${ }^{1}$ \\ 1Jurusan manajemen, Universitas Tarumanagara Jakarta \\ Email:sannye@fe.untar.ac.id \\ Email: thioliesha@yahoo.com
}

\begin{abstract}
ABSTRAK
Tujuan kegiatan adalah memberdayakan pengecer dalam memahami manajemen ritel yang digerakkan oleh pelanggan, membuat kemasan produk yang lebih baik dari pesaing. Mengingat kondisi usaha ritel menghadapi persaingan yang sangat tajam, maka untuk memenangkan persaingan perlu memahami siapa dan apa yang diinginkan oleh konsumen. Kajian dilakukan pada mitra usaha kecil ritel yang terdapat di pasar tradisional Kosambi. Mengingat permasalahan yang dihadapi mitra minimnya pengetahuan tentang manajemen ritel yang berorientasi pelanggan, kemasan produk yang kurang baik. Menyebabkan mitra sulit untuk menghadapi persaing. Berdasarkan permasalahan yang terdapat pada mitra tersebut, maka Tim PKM Untar merasa perlu dalam melakukan kegiatan PKM dalam upaya meningkatkan pengetahuan mitra. Metode yang ditawarkan dalam kegiatan ini adalah pemberian pengetahuan tentang strategi manajemen ritel. Melakukan pendampingan membuat kemasan produk yang lebih bagus, tahan lama, bermerek dan tidak cepat robek. Hasil kegiatan menujukkan mitra sangat berantusias mengikuti sosialisasi dan sangat menyukai kemasan produk yang telah berhasil dibuat oleh Tim. Sehingga dari kegiatan tersebut masalah yang dihadapi mitra dapat segera teratasi. Dengan demikian diharapkan mitra dapat meningkatkan keunggulan bersaing berkelanjutan.
\end{abstract}

Kata Kunci: Manajemen ritel, Strategi, Kemasan.

\section{PENDAHULUAN}

Bisnis ritel memberikan kontribusi pada perekonomian nasional. Pentingnya bisnis ritel dalam menopang ekonomi juga terdapat pada data ekonomi nasional www.depkop.go.id mengemukakan dalam lima tahun belakangan ini, industri ritel memiliki kontribusi terbesar kedua terhadap GDP setelah industri pengolahan, bahkan, dalam penyerapan tenaga kerja, industri ritel berada di posisi kedua setelah sektor pertanian, karena itu, industri ritel dapat dikatakan sebagai industri yang menguasai hajat hidup orang banyak,alasannya, hampir $10 \%$ penduduk Indonesia menggantungkan hidupnya dengan berdagang. Untuk itu bisnis ritel harus tetap eksis dan dijaga keberlanjutannya. Aplalagi saat ini maraknya ritel online. Merupakan pesaing yang tidak dapat dianggap rendah oleh bisnis ritel yang konvensional.

Banyaknya peritel konvensional baik di pasar tradisional maupun modern yang tidak mampu bertahan, dan tidak dapat melanjutkan usahnya. Hal ini terkait dengan kurangnya memahami strategi manajemen ritel dan pengelolaan keuangan yng kurang baik dan kemasan produk yang kurang layak, mudah robek dan tidak menarik.

Sementara itu Morgen dan Hunt (1995), Homburg (2002), Berman (2010) menyarankan bahwa tujuan utama membangun sebuah eceran adalah membangun keunggulan bersaing dengan menerapkan berbagai strategi yang membentuk keunggulan bersaing; berupa keunggulan differensiasi, fokus dan penambah nilai. (Davidson 1998) . Nandakumar et al., (2010), menyebutkan bahwa strategi usaha ritel sangat diperlukan dalam membangun keunggulan bersaing. Selain itu Bellavance,et al.,(2013). Camison dan Lopez (2010) menunjukkan perusahaan kecil dan menengah yang mengoptimalkan sumber daya finansial mampu meningkatkan kemampuan bersaing melalui kemasan yang menarik. 
Kenyataan di lapangan menunjukkan peritel yang menjadi mitra adalah ibu Susiana, sebagai pemilik toko Laris Jaya, dalam menjalankan usaha kurang memiliki modal untuk membuat kemasan yang bagus. Selain itu kurangnya pengetahuan akan strategi manajemen ritel dan menyusun laporan keuangan dengan benar. Sehingga untuk berkembang sangat sulit, ditambah persaingan bisnis ini semakin lama dirasakan peritel makin banyak. Untuk itu diperlukan suatu upaya dalam meningkatkan pengetahuan peritel dalam membangun suatu strategi dalam meningkatkan usaha ritelnya. Seharusnya usaha ritel menjadi perhatian dari berbagai kalangan baik akademisi maupun praktisi dalam membantu keberlanjutan usaha di masa depan. Berbagai cara perlu dilakukan seperti seperti menyumbangkan ilmu penetahuan yang dibutuhkan dalam menjalankan usaha. Memberikan dukungan bagi pengembangan dan kemajuan bisnis ritel melalui melalui pelatihan dan pendampingan. Berdasarkan observasi awal ke mitra maka yang menjadi , prioritas permasalahan adalah: Bagaimana memperkenalkan Manajemen ritel yang digerakkan oleh pelanggan dalam meningkatkan keunggulan bersaing usaha ritel .Bagaimana cara mensosialisasikan Stategi pada peritel usaha kecil di Pasar Tradisional Cengkareng. Bagaimana pendampingan membuat desain kemasan produk ritel, agar dapat meningkatkan nilai jual produk melebihi pesaing

Untuk itu tujuan kegiatan dapat mendorong aktivitas usaha ritel agar dapat menggunakan strategi tersebut. Dalam menjalankan usaha ritel untuk jangka waktu yang panjang.

\section{TARGET DAN LUARAN}

Luaran yang ditargetkan selesai dari kegiatan pengabdian masyarakat ini adalah:

1. Memperkenalkan strategi perencanaan usaha ritel bagi kelompok ritel di daerah Cengkareng khususnya di pasar tradisional. Model ini sebagai panduan bagi mereka dalam menjalankan usaha ritel dalam menghadapi pesaingan ritel, Aspek ini berkaitan langsung dalam aspek manajemen. Spesifikasi model yang diberikan pada kelompok peritel sebagai acuan aktivitas manajemen perencanaan ritel, proses untuk merencanakan strategi usaha ritel yang merupakan langkah-langkah yang harus dilalui oleh pebisnis ritel untuk membangun rencana strategis usaha ritel yang berhasil, mulai: strategi penetapan misi bisnisnya. Pernyataan misi usaha ritel harus bisa memberikan penjelasan umum mengenai target segmen dan retail format yang menjadi perhatian dari usaha ritelitu sendiri. Membangun Situasi Audit. Dengan memperhatikan elemen-elemen dalam situasi audit ini adalah : Faktor Pasar, faktor persaingan, faktor lingkungan dan analisis kekuatan dan kelemahan pebisnis retail. Mengidentifikasi Peluang Strategis dengan mempersiapkan beberapa alternatif strategi yang akan digunakan usaha ritel untuk meningkatkan penjualannya, mengevaluasi alternatif strategis, membuat tujuan spesifik dan mengembangkan gabungan retail (retail mix) untuk mengimplementasikan strategi serta mengevaluasi peforma dan membuat Penyesuaian

2. Mensosialisasikan proses perencanaan usaha ritel bagi kelompok ritel traisional di pasar Laris Kabupaten Cengkareng. Metode ini untuk memberi pembinaan/pelatihan agar mereka mengelola usaha dengan cara yang lebih baik dan teratur. Spesifikasi pelatihan diberikan tentang jenis jenis proses perencanaan strategi yang harus dimiliki bagi peritel dalam menjalankan usaha. Dalam pelatihan melakukan penjabaran tentang proses perencanaan strategi dalam buku panduan perncanaan ritel.

3. Memperkenalkan desain produk yang sebaiknya digunakan dalam meningkatkan nilai jual produk yang ditawarkan kepada konsumen. Spesifikasi model yang ditawarkan adalah: melakukan studi kelayakan terhadap kemasan produk yang ditawarkan produk yang telah memilki nama merek, membuat beberapa alternatif pilihan desain kemasan dan membuat kemasan yang sesuai dengan produk yang dijual kepada konsumen. 


\section{METODE PELAKSANAAN}

\section{Solusi Untuk Mengatasi Masalah Mitra}

Berdasarkan hasil diskusi dengan kelompok ritel di Cengkareng, prioritas masalah dihadapi oleh kelompok tersebut sebagai berikut:

1. Aspek manajemen, yang terkait dengan perencanaan strategi ritel, dimana peritel belum memilki pengetahuan akan perencanaan strategi ritel yang perlu dilakukan bagi pengecer dalam menjalankan usaha sehinga bisnis ritel banyak yang mengalami kegagalan ditengah jalan.. Solusi yang ditawarkan adalah: a. Membuat panduan model perencanaan strategi usaha ritel bagi kelompok usaha ritel yang berlokasi di Cengkareng. b. Melakukan pelatihan atas panduan yang dibuat agar dapat memberikan pemahaman yang lebih jelas dalam melakukan bisnis ritel.

2. Aspek produksi terkait dengan masalah desain kemasan produk yang dapat meningkatkan nilai jual produk yang ditawarkan kepada konsumen. Dengan menambah suatu atribut produk yang dapat membedakan produk ritel pada pesaing, dilakukan pilot project pada satu usaha ritel sebagai percontohan untuk melakukan kegiatan ini. Solusi ysng ditawarkan adalah: Membuat desain kemasan usaha yang disesuaikan dengan hasil studi banding pada ritel moderen, jenis produk yang akan ditawarkan, ukuran produk maupun kondisi pesaing .

\section{HASIL KEGIATAN DAN PEMBAHASAN}

\section{A. Profile Tempat Usaha Ritel}

Usaha ritel didirikan di Pasar Laris Kosambi blok I No.5, RT.04/RW.01, Duri Kosambi, Cengkareng, Kota Jakarta Barat, Daerah Khusus Ibukota Jakarta 11750. Lokasi pasar terletak sangat Strategis berdiri di lahan 5 hektar terdiri dari Apartment, Ruko Citywalk dan area perumahan. Pasar Laris Modern dibangun dengan konsep pasar modern. Dimana pasar yang identik dengan sumpek, becek dan kumuh tidak berlaku untuk pasar ini. Konsep pasar laris kosambi didirikan dengan kondisi pasar berbeda. Seperti halnya pasar modern layaknya. Di pasar modern ini, semua lapak-lapak para pedagangnya tertata rapi dan dipisah berdasarkan jenis barang yang diperdagangkan. Misalnya lapak basah untuk ikan, daging, dan ayam tidak bercampur dengan lapak kering untuk sayur dan buah-buahan. Tidak hanya rapi saja, tetapi juga memberikan kenyamanan kepada pengunjungnya. Di pasar modern, lantai-lantainya sudah dilapisi dengan keramik dan bangunan pasarnya juga diberi atap. Sehingga pengunjung yang datang tidak kehujanan ataupun kepanasan. Gambar berikut ini peta lokasi dan pintu masuk pasar
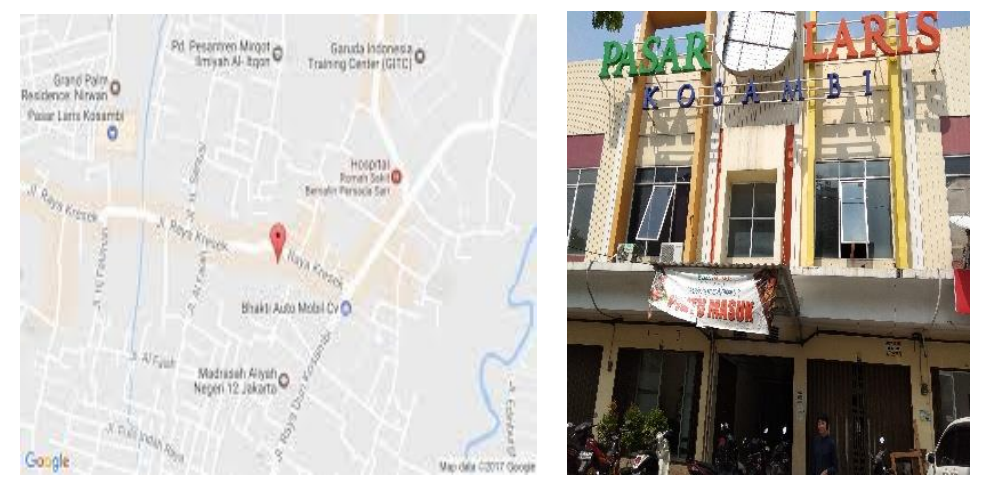

Gambar 1. Peta Lokasi dan pintu Masuk Pasar

Berbagai jenis yang diperdagangkan didalam pasar, sandang maupun pangan. Mulai dari kebutuhan pokok sehari-hari, beras sayur mayur, ikan, daging dagingan, bumbu bumbu sampai 
kepada kebutuhan sekunder lainnya seperti emas, pakaian, sepatu, perlengkapan rumah tangga dan lainnya
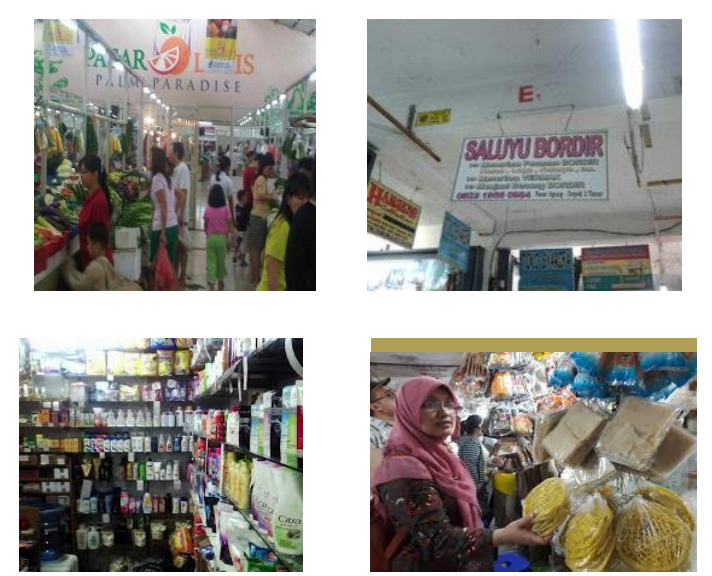

Gambar 2. Beberapa Jenis Barang Yang Dijual Di Pasar Laris

\section{B. Profil Pedagang Ritel}

Kegiatan PKM dilakukan dengan mensosialisasikan pedoman perencanaan ritel, kepada kelompok pedagang ritel. Pedagang ritel yang dipilih tergolong dalam kelompok ritel produk fashion. Berikut merupakan deskripsi dari kelompok ritel yang terdapat di pasar Laris Kosambi yang meliputi Toko Laris Jaya dapat digambarkan sebagai berikut:
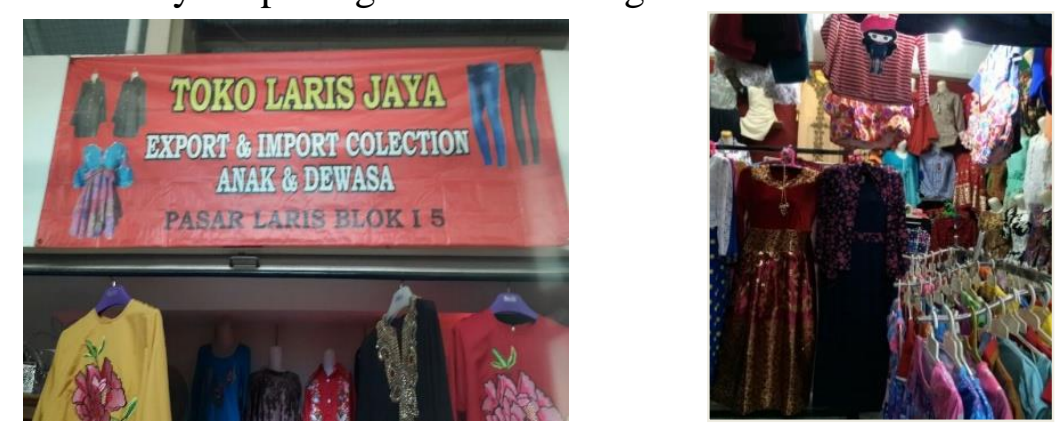

Gambar 3. Beberapa Jenis Barang Yang Dijual Di Toko Laris Jaya

Ibu Susiana yang biaasanya dipanggil dengan Ibu Ana adalah pemilik sekaligus pekerja ditoko Laris Jaya, berdirinya toko baju ini sudah cukup lama sekitar 8 tahun lamanya. Awalnya ibu mendirikan usaha untuk memenuhi kebutuhan keluarga. Dengan sedikit modal Ibu Ana membuka toko di pasar laris dengan nama toko Laris Jaya. Sistem penjualannya bisa grosir dan eceran, karena tidak semua pembeli bisa membeli dengan sistem grosiran dan sebaliknya. dalam satu bulannya toko ini bisa mere-stock hingga 4 kali, atau seminggu sekali re-stock. Pelayanan dan kualitas barang sangat dipentingkan untuk memberikan kepuasan kepada konsumen atau pelanggan tetapnya, letak toko ini sangat strategis ditengah depan tempat jual sayur mayur, sehingga banyak konsumen yang lalu lalang ditempat ini. Mengenai barang-barang import luar negeri, toko ini bisa dikatakan hampir tidak terpengaruhi oleh barang import tersebut, karena masyarakat di sana tidak begitu mementingkan merk ataupun harga produk, yang terpenting adalah kenyamanan saat barang yang dibeli digunakan. Harga barang yang ditawarkan sangat bervariasi dan sangat competitive.

\section{Membuat Model Strategi Usaha Ritel Untuk Kelompok Ritel .}


Output pertama dirancang dalam kegiatan PKM adalah membuat panduan strategi Perencanaan usaha eceran. Desain ini stratetgi bertujuan untuk memberikan pemahaman agar pemilik toko ritel memiliki pengetahuan akan dalam melakukan pengelolaan eceran secra lebih baik, dan dapat mrenghadapi pesaing. Penyusunan draff panduan dilakukan dengan cara diskusi, membaca buku literatur, bertanya dengan pakar dan melalui hasil penelitian. Model tersebut visualisasikan dalam bentuk panduan dan disosialisasikan kepada komunitas usaha ritel di Toko Laris Jaya Cengkareng. Pemilik Toko Laris Jaya sangat merespon dengan program ini, karena mereka menjadi yakin dan mantap dalam menjalankan bisnis eceran terutama dalam menghadapi persaingan yang semakin pesat. Langkah -langkah perencanaan tersebut adalah:

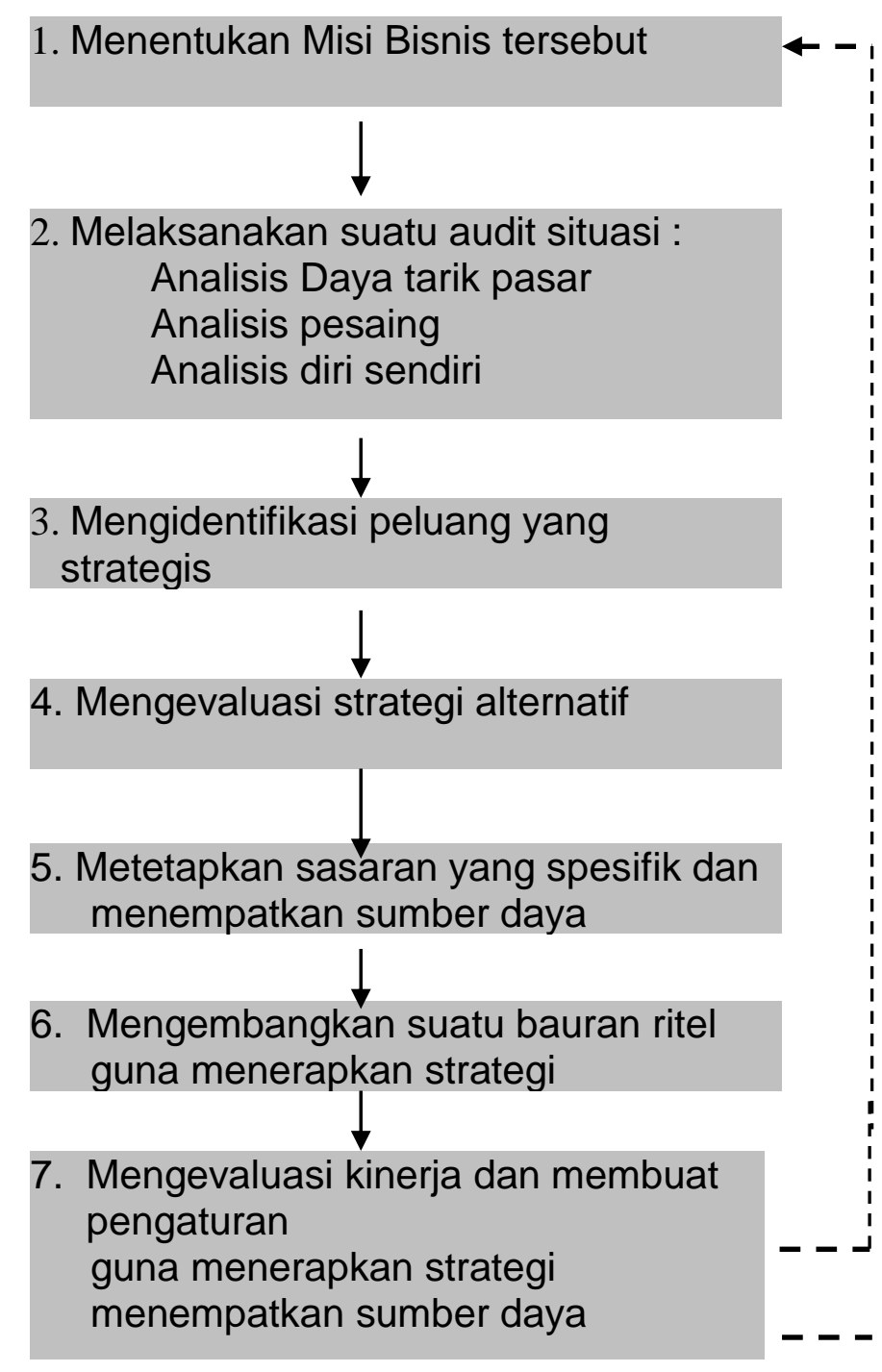

Gambar 4. Langkah Strategi Perencanaan Ritel

Sumber: Levy, Michael and Barton A. Weitz (2014). Retailing Management. New York : McGraw-Hill Companies 


\section{Sosialisasi strategi Perencanaan Ritel}

Proses FGD dilakukan juga pada pembuatan model panduan strategi perencanaan eceran. Para pengecer harus mengatur strategi dalam rangka mempertahankan atau mendapatkan dan meningkatkan konsumen baru. Strategi tersebut berupa Perencanaan ritel, yang merupakan strategi untuk memenangkan persaingan dengan cara seperti memperhitungkan kenyamanan konsumen pada saat berbelanja. Strategi Perencanaan ritel adalah merupakan suatu perencanaan yang disusun selama melakukan kegiatan usaha ritel yang digunakan untuk memuaskan kebutuhan pelanggan dan mempengaruhi keputusan mereka untuk membeli. Perencanaan ritel merupakan saat adanya misi usaha ritel sampai pada akhirnya mengembangkan suatu strategi ritel dan melakukan evalusi terhadap kinerja usaha ritel.

Pada kasus " Toko Laris Jaya", dapat dilihat kondisi dari tiap tahapan yang dimiliki dan perlu disosialisasikan untuk melakukan perbaikan pada tahapan yang masih memilki kelemahan.

\section{Misi Perusahaan}

Saat toko ritel didirikan perlu menetapkan apa yang menjadi misi utama dari usaha, sebagai contoh menjadi toko fashion yang berkualitas dan terpercaya untuk masyarakat di kawasan Cengkareng dan sekitarnya serta memberikan kenyamanan bagi konsumen yang berbelanja di tokonya.

\section{Audit Situasi}

a. Analisis Daya Tarik Pasar

Analisis daya tarik pasar ini meliputi faktor pasar, target pelanggan, perputaran penjualan. Target pelanggan toko ini adalah produk fashion untuk para wanita. Perputaran penjualan tergantung dari hari kerja ataupun hari libur, seperti saat hari libur toko ini bisa mendapatkan omzet yang tinggi, sehari omzet kotor mereka bisa mencapai 5 juta. Lain halnya jika hari kerja, toko menjadi tidak terlalu ramai pembeli sehingga sangat sepi dan menjadi hambatan bagi toko untuk meningkatkan penjualannya.

\section{b. Analisis Pesaing}

Analisis pesaing ini meliputi faktor kompetitif dan analisa kekuatan dan kelemahan. Untuk faktor kompetitif yaitu para pesaing dalam pasar retail terpengaruh oleh masuknya pendagang baik yang berasal dari dalam lingkungan internal atau lokasi yang sama maupun di luar lokasi ritel. Menurut wawancara kami pada salah satu karyawan di Toko, karyawan mengatakan bahwa mereka tidak terlalu memiliki pesaing. Karena Toko ini merasa mereka memiliki sesuatu yang berbeda dari toko-toko lainnya di pasar tradisional.

Untuk analisa kekuatan pada Toko Laris Jaya meliputi :

- Memiliki barang import yang berkualitas, berbeda dari toko lainnya.

- Toko ini dapat menjual secara grosir dan retail dengan kualitas produk yang baik.

- Kualitas produk yang ditawarkan bagus, bervariasi.

- Harga produk juga terjangkau dan bervariasi.

- Penjual memberikan diskon untuk produknya bagi konsumen yang membeli dalam jumlah besar.

Untuk analisa kelemahan pada Toko Laris Jaya meliputi :

- Tidak melakukan iklan.

- Penjualan produk tidak dipasarkan secara online.

- Tidak terdapat kamar pas untuk mencoba bajunya karena kurangnya modal.

- Banyaknya persaingan toko yang menjual produk yang sejenis.

- Pembayaran masih hanya menerima cash tidak dapat menggunakan kartu kredit maupun debit.

- Karyawan kurang tanggap dalam hal melayani konsumen yang berbelanja. 
- Kemasan produk tidak menarik, masih menggunakan plastik biasa tidak memiliki keistimewaan 3. Mengidentifikasi Peluang

Peluang yang ada pada Toko Laris Jaya ini meliputi :

a. Kebutuhan masyarakat akan produk, terutama produk fashion untuk wanita.

b. Daya tarik pasar kecenderungan untuk kelas menengah ke bawah.

\section{Strategi Alternatif}

Ditengah himpitan persaingan antara toko-toko disekitar Toko Laris Jaya melakukan alternatif strategi yaitu dengan menjual variasi produk fashion wanita yang adakalanya tidak dimilki oleh toko fashion yang lain. Selain strategi variasi produk, Toko Laris ini juga melakukan strategi variasi harga yang berkompetitif dengan para pesaing. Hal inilah yang membuat Toko dapat bertahan di pasar tradisional Laris Kosambi Cengkareng.

\section{Sasaran Spesifik dan Mengalokasikan Sumber Daya}

Sasaran spesifik Toko Laris adalah :

a. Harga produk yang terjangkau bagi konsumen.

b. Target produk adalah khusus untuk wanita.

c. Penampilan produk bagus dan berkualitas bagi yang memakainnya.

\section{Mengembangkan Suatu Perencanaan Ritel}

Perencanaan retail adalah kombinasi elemen-elemen produk, harga, lokasi, personalia, promosi, dan presensi atau tampilan untuk menjual barang dan jasa pada konsumen akhir yang menjadi sasaran pasar. Dalam hal ini Toko menggunakan beberapa strategi Perencanaan ritel meliputi :

a. Produk (Barang Dagangan)

Toko Laris ini menawarkan berbagai produk fashion kebutuhan wanita, dengan khusus menentukan target konsumen wanita dengan variasi ukuran produk yang banyak yaitu S, M, L, XL. Dan juga Toko Laris Jaya ini menyediakan produk dengan variasi kualitas produk untuk konsumen kelas menengah dan konsumen kelas bawah agar memiliki segmen pasar yang luas. Kombinasi produk yang di jual oleh Toko Laris Jaya ini berkaitan dengan keragaman barang yang bersangkutan. Keragaman barang Toko Laris Jaya ini dapat dilihat dari berbagai sudut, salah satunya yaitu keragaman dari segi ukuran dan model. Selanjutnya dalam keragaman barang juga harus memperhatikan bahan yang digunakan.

Produk-produk yang dijual Toko Laris Jaya ini antara lain :

1. Baju kaos wanita import dan bukan

2. Dress

3. Topi

4. Kemeja wanita

5. Celana jeans

6. Seragam Sekolah

7. Pakaian Muslim dan Kerudung

b. Penetapan Harga

Harga adalah nilai suatu barang yang dinyatakan dengan uang. Toko Laris Jaya ini menetapkan harga yang cukup terjangkau untuk para konsumennya. Variasi harga yang ditetapkan kisaran Rp 45.000,- sampai Rp 250.000,-. Untuk baju kaos wanita kisaran harganya Rp 45.000,- sampai Rp 
150.000,-. Dress ditetapkan dengan harga > Rp 100.000,-. Selanjutnya untuk topi ditetapkan dengan harga $>$ Rp 40.000,-. Kemeja wanita ditetapkan dengan kisaran harga Rp 50.000,- sampai Rp 120.000,- dan celana jeans dijual dengan harga > Rp 100.000,-. Busana muslim kisaran harga Rp.100.000 sampai Rp.250.000

c. Iklan dan Program Promosi

Toko Laris Jaya tidak melakukan iklan maupun promosi, lewat brosur ataupun media iklan yang lainnya. Mereka hanya melakukan promosi WOM. Dan juga terkadang mereka memberikan beberapa potongan harga untuk konsumen yang membeli dalam jumlah tertentu.

\section{d. Desain Toko dan Perdagangan Visual}

Desain Toko Laris Jaya tidak memilki desain toko yang menarik, desain yang dibuat berdasarkan banyaknya barang yang dimilki. Toko Laris Jaya ini tidak terlalu besar, display produknya dibuat dengan sesuai dengan jenis produknya dengan menggunakan beberapa manekin, sedangkan untuk produk fesyen yang di obral, disusun dalam wagon.

\section{e. Lokasi}

Lokasi Toko Laris Jaya ini strategis, berada didalam pasar yang letaknya berhadapan dengan toko sayur mayur dan toko bumbu giling. Sehingga kadang kadang saat penjual bumbu melakukan proses penggilingan akan menjadi berisik dan baunya sangat tajam. Tetapi tempat ini cukup ramai jalan lintas konsumen.

\section{f. Pelayanan}

Pelayanan yang diberiukan pemilik cukup ramah. Yang berbelanja dianggap saudara. Bahkan dari banyaknya konsumen yang ada, sudah menjadi teman pemilik.

\section{Mengevaluasi dan Menetapkan Strategi Keunggulan Bersaing}

Secara keseluruhan Toko Laris Jaya sudah dapat dikatakan mendapatkan pasar sasarannya, namun pada kondisi tertentu diperlukan untuk dipertimbangkan kembali agar permintaan yang tinggi tidak hanya pada saat weekend saja sehingga perputaran omzet dapat stabil setiap bulannya. Dan perlu juga memperbaiki beberapa hal seperti kondisi toko dan kinerja karyawannya yang dapat diberi bimbingan dahulu sebelumnya sehingga dapat meningkatkan minat konsumen untuk berbelanja di Toko Laris Jaya.

Dalam kegiatan tersebut telah melibatkan beberapa mahasiswa program S1 manajemen . Hasil pantauan terhadap profil responden dan program sosialisasi panduan strategi ritel yang berhasil didokumentasikan pada gambar berikut:
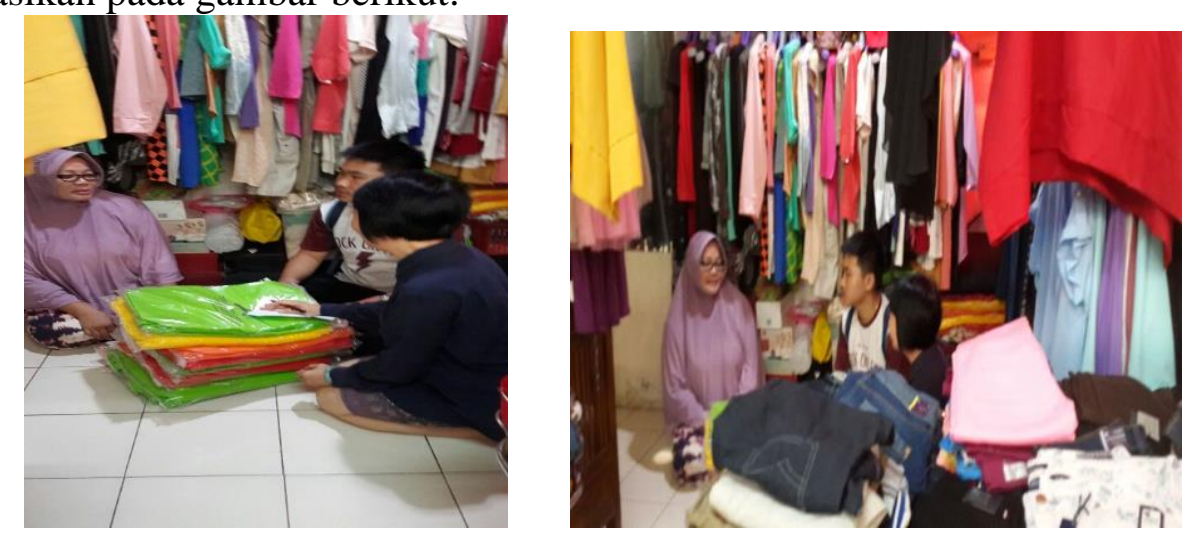

Gambar 5. Saat Sosialisasi 
Kegiatan PKM juga dilakukan untuk pengembangan produk, agar lebih memiliki daya jual yang lebih tinggi. Salah satu kegiatan yang dilakukan adalah membuat kemasan produk, yang tadinya hanya berupa kantong plastik putih biasa yang mudah robek dan tidak memiliki manfaat lebih. Kegiatan ini dibuat menciptakan suatu kemasan produk yang menggunakan kain yang berwarnawarni, dan disertai dengan nama merek dan nama toko ritel.Variasi tas kain sebagai kemasan menyesuaikan motif produk ritel yang dijual. Warna dasar kemasan bersifat soft mengikuti dominasi warna produk. Tas kemasan bertuliskan merek Toko Laris Jaya. Material kemasan tidak mudah robek, tahan lama dan dapat berfungsi sebagai tas bagi konsumen. Ipteks ditawarkan meliputi langkah berikut:
a. Menyiapkan bahan Spunbond non woven 70 gram
b. Desain model (nama merek, logo, alamat dan lainnya)
c. Bahan dipotong sesuai dengan ukuran yang diinginkan
d. Dilakukan sablon terhadap model yang didesain
e. Dimasukkan dalam mesin lipat dan di press dengan mesin hot press

Melalui keterlibatan mahasiswa, mempermudah dalam mendesain kemasan produk dengan tujuan untuk meningkatkan daya saing produk. Model desain kemasan seperti gambar berikut:
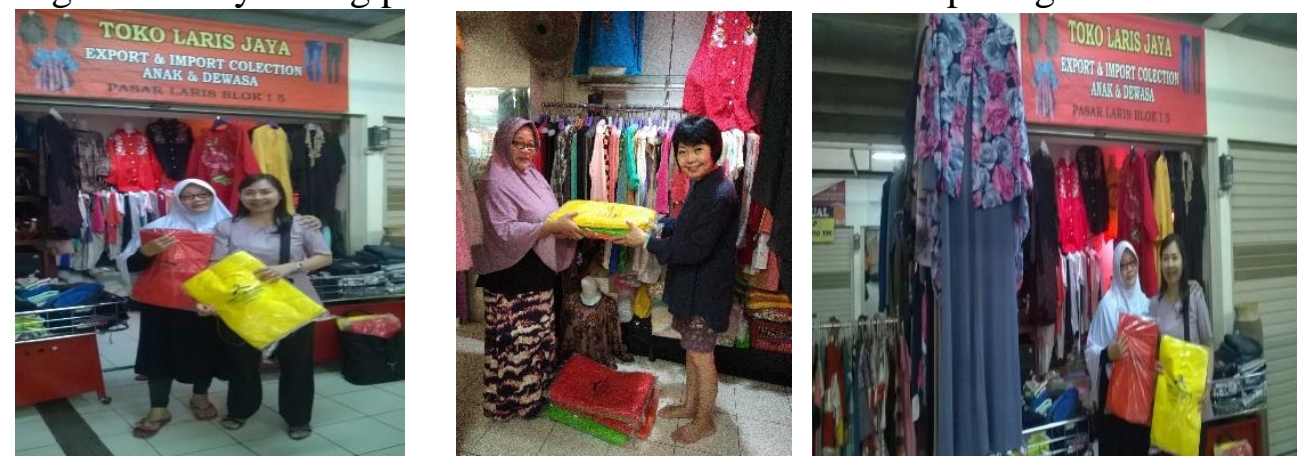

Gambar 6. Model Kemasan Produk Ritel yang Ditawarkan

\section{KESIMPULAN DAN SARAN}

\section{A. Kesimpulan}

Berdasarkan pelaksanaan kegiatan ini, diperoleh kesimpulan sementara sebagai berikut:

1. Panduan strategi perencanaan usaha ritel yang sudah tersusun dengan melakukan FGD, observasi dan wawancara dengan pihak terkait. Sosialisasi skala kecil sudah dilakukan pada beberapa kelompok usaha ritel yang terdapat di pasar Laris.

2. Pelatihan perencanaan ritel yang perlu dilakukan dalam menjalankan bisnis secara berkelanjutan dan unggul dalam persaingan..

3. Pendampingan membuat kemasan produk ritel yang disesuaikan dengan jenis produk yang dijual, dan dibuat menggunakan bahan kain yang tahan lama dan memiliki variasi warna yang beragam dan juga berfungsi sebagai tas.

\section{B. Saran}

Perbaikan secara berkelanjutan usaha ritel dapat dulakukan antara lain dapat dikembangkan dalam kajian selanjutnya.

1. Proses pembinaan kontinuitas usaha, melalui pemetaan terhadap permasalahan usaha ritel.

2. Penerapan dan pengembangan produk melalui analisis pasar. 
3. Melakukan kerja sama dengan mitra, untuk relokasi layout, display, pencahayaan yang sudah tidak layak lagi.

\section{Ucapan Terima Kasih}

Kepada Direktur dan Staff DPPM Universitas Tarumanagara yang telah memberikan dukungan sehingga PKM ini terselesaikan.

\section{REFERENSI}

Bellavance F, Landry, S \& Schiehll, E 2013, „Procedural Justice in Managerial Performance Evaluation: Effect of Subjectivity, Relationship Quality, and Voice Opportunity"e, The British Accounting Review, 45, 149-166

Berman, Barry \& Joel R. Evans. (2010). Retail Management, a Strategic Approach, (8th Edition). New Jersey: Pearson

Camison, Cesar, \& Lopez Ana Villar. 2010. Effect of SMEs International Experience on Foreign Intensity and Economic Performance: the Mediating Role of Internatinally Exploitable Assets and Competitive Strategy, Journal of Small Business Management, 48(2). Pp 116151

Davidson, R.William.,(1998)," Retailing Management," 6e. Canada : John Wiley \& Son, Inc, Homburg, Hoyer dan Fassnacht ( 2002)," Service orientationof Retailers Business Strategy Dimensions. Antecedents, and Performance Outcomes, Journal Of Marketing, October,Vo1.66,pp.86- 101.

Levy, Michael and Barton A. Weitz (2014). Retailing Management. New York : McGraw-Hill Companies

Morgan, Robert M and Shelby D. Hunt, (1995) “ The Commitment Trust Theory Of Relationship Marketing”, Journal Of Marketing, 58 July, 20-38.

Nandakumar, M.K; Abby Ghobadian \& Nicholas O'Regan. (2010). Bussiness-Level Strategy and Performance : The Moderating Effect of Environment and Structure. Management Decision, 48, 6, 907-939.

www.depkop.go.id. Data UMKM Tahun 2006-2011. Di akses pada tanggal 12 Januari 2012 